\title{
Actions for sustainable forest ecosystems under air pollution and climate change
}

\author{
Takeshi IzUTA $^{\mathrm{a}, \dagger}$

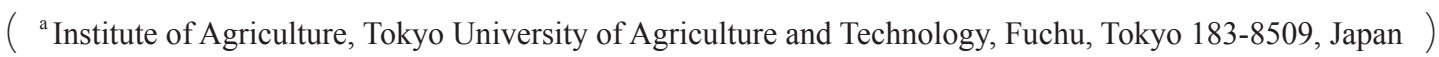

In the 21 st Century, air pollution and climate change are very serious environmental problems for forest ecosystems all over the world. Therefore, many researches are needed for understanding the responses of forest ecosystems to air pollutants such as ozone $\left(\mathrm{O}_{3}\right)$, a main component of photochemical oxidants, and climate change such as elevated atmospheric $\mathrm{CO}_{2}$ and air temperature. The 28th IUFRO (International Union of Forest Research Organizations) Biennial Conference of Research Group 7.01 (Impacts of Air Pollution and Climate Change on Forest Ecosystem) entitled "Actions for Sustainable Forest Ecosystems under Air Pollution and Climate Change" was held in Fuchu, Tokyo, Japan (Tokyo University of Agriculture and Technology) on 22-26 October, 2017. At this biennial conference, we had an excellent opportunity to discuss close relationships among air pollution, climate change and forest ecosystems.

This special issue of Journal of Agricultural Meteorology is dedicated to the original articles derived from the organized sessions of the 28th IUFRO Biennial Conference of Research Group 7.01 as follows: (1) Asian forest ecosystem under changing environment, (2) Developing detection, monitoring and evaluation, (3) Ecophysiological and genetic understanding of plant responses, (4) Water and nutrient cycles in forest ecosystems, (5) Modelling and risk assessment, and (6) Forest ecosystems under multiple stressors. The following briefly introduces the 5 original articles in this special issue.

Marozas et al. (2019) evaluated the differences in gas exchange characteristics and chlorophyll fluorescence of tree species prevailing in Lithuania (Scots pine, Norway spruce and Silver birch) and their physiological responses to water stress. Under moderate drought conditions, all tree species demonstrated reduced photosynthetic rate, lower stomatal conductance, transpiration rate, water use efficiency (WUE) and instantaneous carboxylation efficiency. No significant changes of maximal chlorophyll fluorescence $\left(\mathrm{F}_{\mathrm{v}} / \mathrm{F}_{\mathrm{m}}\right)$ among the tree species were detected during the different weather conditions. Scots pine demonstrated the highest tolerance whereas Norway spruce had the highest sensitivity to drought conditions. Silver birch was the least sensitive to temperature and humidity conditions. Baumgarten et al. (2019) investigated species-specific sap flux, transpiration and water use efficiency of growth (WUE) at mixed hemi-boreal forest ecosystems during temporary moderate dry periods in the main growing season in Lithuania. They assumed that Scots pine trees are less affected by temporarily drought events than Norway spruce. Birch trees (silver birch and downy birch) exhibited significantly highest sap flux during dry periods at the water limited site whereas quite low WUE

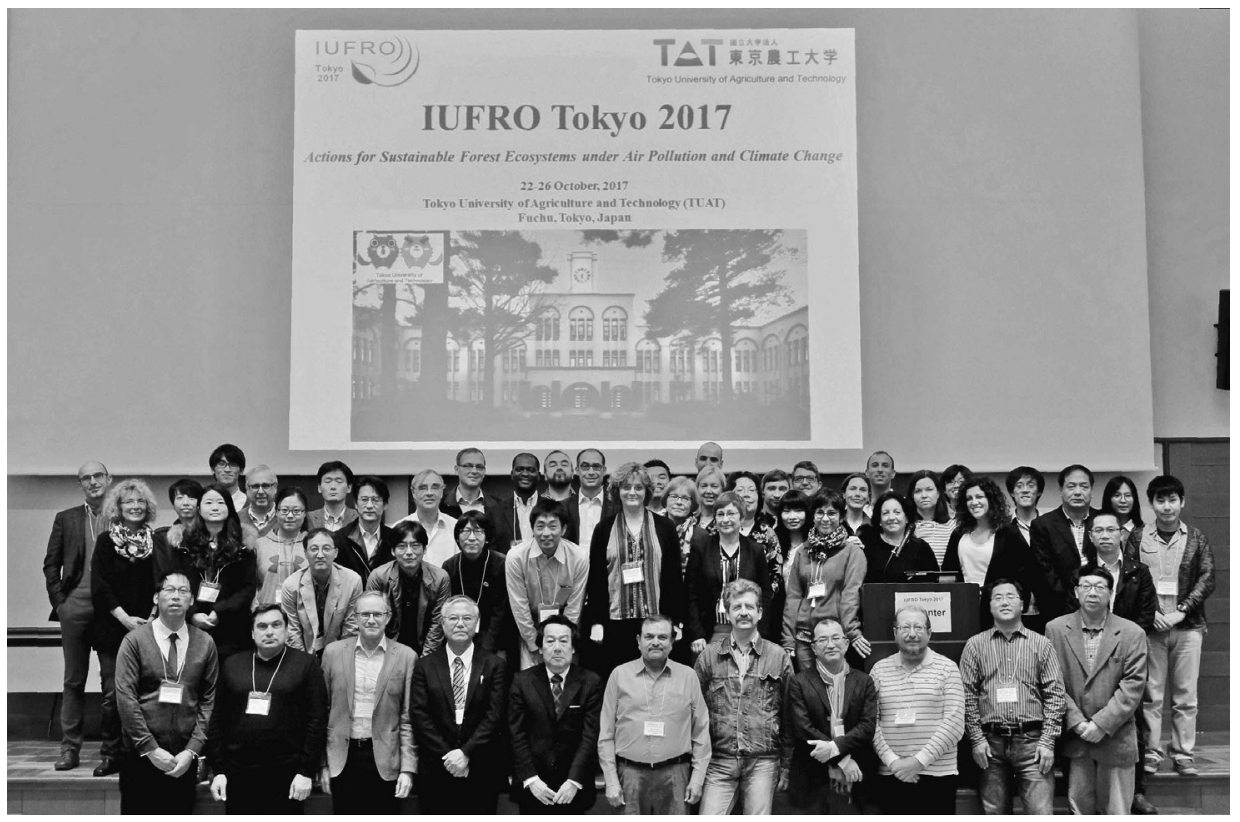

Photo 1. Participants of IUFRO Tokyo 2017.

${ }^{\dagger}$ Corresponding Author: izuta@cc.tuat.ac.jp

DOI: 10.2480/agrmet.D-18-00101 
was not different between the forest sites with different drought susceptibility. Therefore, birch trees may compete with Scots pine trees at the study sites in terms of water consumption and growth in the future. Yamaguchi et al. (2019) investigated the atmospheric deposition of long-range transported particulate matter (PM) on the needle surface of mature Japanese cypress (Chamaecyparis obtusa) grown in Nagasaki, Japan. They indicated that the long-range transported $\mathrm{PM}$ including $\mathrm{Pb}$, $\mathrm{Ni}, \mathrm{Cu}, \mathrm{Zn}$ and $\mathrm{As}$, originated from the anthropogenic sources in China, and deposited on the needles of C. obtusa grown in Nagasaki. Watanabe et al. (2019) investigated the effects of $\mathrm{O}_{3}$ on soil respiration rate of Siebold's beech seedlings (Fagus crenata) grown under different soil-nutrient conditions. No significant effect of $\mathrm{O}_{3}$ on soil respiration was mainly attributable to no response of fine root dry mass to elevated $\mathrm{O}_{3}$. Soil nutrient supply decreased soil respiration rate in August. Their results emphasize the importance of fine roots in the response of soil respiration to elevated $\mathrm{O}_{3}$. Manaka et al. (2019) conducted a monthly sampling survey of the Ganges River in Bangladesh during 2011-2014 and measured the chemical composition of the river water. Their results suggest that water during the rainy season, which has high partial pressure of $\mathrm{CO}_{2}$ $\left(p \mathrm{CO}_{2}\right)$, temperature and water current velocity, releases $\mathrm{CO}_{2}$ into the atmosphere more efficiently $\left(150 \mathrm{~mol} \mathrm{~m}^{-2} \mathrm{year}^{-1}\right)$ than that during the dry season $\left(20 \mathrm{~mol} \mathrm{~m}^{-2}\right.$ year $\left.^{-1}\right)$. In addition, they collected groundwater samples in Bangladesh and observed surprisingly high $p \mathrm{CO}_{2}$ values. Groundwater in this area is likely to transport abundant dissolved inorganic carbon to the ocean.

I hope this special issue will help readers to realize that further multidisciplinary researches on the effects of air pollution and climate change on forest ecosystems are needed for effective actions towards sustainable forest ecosystems.

\section{References}

Baumgarten M, Hesse BD, Augustaitienè I, Marozas V, Mozgeris G, Byčenkienė S, Mordas G, Pivoras A, Pivoras G, Juonytė D, Ulevičius V, Augustaitis A, Matyssek R, 2019: Responses of species-specific sap flux, transpiration and water use efficiency of pine, spruce and birch trees to temporarily moderate dry periods in mixed forests at a dry and wet forest site in the hemi-boreal zone. Journal of Agricultural Meteorology 75(1), 13-29.

Manaka T, Hossain HMZ, Yoshimura T, Suzuki A, Kawahata $\mathrm{H}, 2019$ : Monthly changes in $p \mathrm{CO}_{2}$ in the Ganges River: implications for carbon release from soil to the atmosphere via inland waters. Journal of Agricultural Meteorology 75(1), 47-55.

Marozas V, Augustaitis A, Pivoras A, Baumgarten M, Mozgeris G, Sasnauskienè J, Dautartè A, Abraitienè J, Bičenkienė S, Mordas G, Ulevičius V, Matyssek R, 2019: Comparative analyses of gas exchange characteristics and chlorophyll fluorescence of three dominant tree species during the vegetation season in hemi-boreal zone, Lithuania. Journal of Agricultural Meteorology 75(1), 3-12.

Watanabe M, Okabe S, Kinose Y, Hiroshima H, Izuta T, 2019: Effects of ozone on soil respiration rate of Siebold's beech seedlings grown under different soil nutrient conditions. Journal of Agricultural Meteorology 75(1), 39-46.

Yamaguchi M, Tsuji S, Ogata K, Ide H, Matsushita T, Murao N, 2019: Deposition of long-range transported particulate matter on the needle surfaces of Japanese cypress (Chamaecyparis obtusa) grown in Nagasaki located in the western region of Japan. Journal of Agricultural Meteorology 75(1), 30-38. 